\title{
Family Construction Models for Weak Economic Communities That Are Safe to the Environment
}

\author{
Bakhrani Abdul Rauf, Mithen Lullulangi, Faizal Amir
}

Engineering Department, Universitas Negeri Makassar, Makassar, Indonesia

\section{Email address:}

bakhrani@unm.ac.id(B.A. Rauf),mithen@unm.ac.id(M. Lullulangi), faizalamir64@unm.ac.id(F.Amir)

\section{To cite this article:}

Bakhrani Abdul Rauf, Mithen Lullulangi, Faizal Amir. Family Construction Models for Weak Economic Communities That Are Safe to the Environment. American Journal of Construction and Building Materials. Vol. 3, No. 2, 2019, pp. 30-34. doi: 10.11648/j.ajcbm.20190302.12

Received: October 19, 2019; Accepted: November 7, 2019; Published: November 17, 2019

\begin{abstract}
The specific objectives of this study are: (1) to design a family latrine construction model that uses local raw materials for a weak economy community in the highlands of South Sulawesi province that is environmentally safe, (2) to find local materials that make up the latrine construction, and (3) find the right method for applying the latrine construction model. The research locations were the highlands of Maros Regency, Barru Regency and Soppeng Regency. The respondents of this study were 150 families were also selected purposively. The research variables are: 1) the family toilet construction model, 2) the construction material for the latrine construction, and 3) the method for applying the latrine model. Data collection by questionnaire. The analysis used is descriptive qualitative analysis. The results showed: 1) the construction model of family latrines for the economically weak community in the highlands of South Sulawesi Province: (a) the construction of a septictank is a pair of waterproof plaster plaster bricks, (b) has permeation, (c) latrine floors and rooms simple karamic baths, (d) locally made goose necks, (e) wall tiles in smooth plaster bricks, (f) local wooden roof truss, (g) local wooden roof coverings, bamboo or zinc, and (h) latrine doors local wood boards, 2) local materials making up construction, namely split stone, sand, gravel, local wood, bamboo and palm fiber. Other materials are cement, zinc, simple ceramics and klosed neck swans, and 3) the methods or steps taken to implement the family latrine model are: (a) introducing the latrine construction model and the material used, (b) explaining the purpose, benefits of latrines, the effects of feces that are disposed of randomly, (c) describe the local material used, and (d). provides a model of latrine model for weak economic families in the highlands.
\end{abstract}

Keywords: Family Latrines, Society, Economy Is Weak, Plateau, Environment

\section{Introduction}

Law of the Republic of Indonesia No. 32 of 2009 concerning Protection and Management of the Environment is explained that the environment is a unity of space with all objects, power, conditions and living things, including humans and behavior that affect the continuity of life and well-being of humans and beings other life [1]. From Law No. 32 of 2009 it can be understood that humans are the determinant in managing their environment. Therefore, the pros and cons of the built environment of humans are very much determined by humans themselves.

Dyah at al, The environment is composed by three important components, namely: (1) the abiotic environment or physical environment in which there is air, land, water and so on (2) the biotic or biological environment in which there are plant elements and elements animal elements and the like, and (3) the social environment in which there are social systems, culture, welfare and so on [2]; Tandjung, and Singh, explained that these three environmental components depend on one another and need to be maintained so that they do not experience environmental degradation [3].

The theory that underlies this study is successively described as follows. The Indonesian Ministry of Health states that human feces are a source of disease so they need to be disposed of in a toilet. Feces that are not managed properly and can affect human health [4]. Chandra, stated that the family toilet is a building used to dispose of and collect human excrement or faeces commonly known as latrines / toilets [5]. Salvato and Beck, stated that the family toilet building must meet health requirements namely: protected from heat and rain, does not cause odor, and enough water to clean it [6]. Firmansyah, stated that latrines 
in rural Indonesia can be classified into 2 types namely cemplung latrines and septictank / goose neck latrines [7]. Notoatmodjo, stated that latrines are said to be healthy if: they do not pollute the surrounding surface soil, do not cause foul odors, and do not pollute the surrounding surface water [8].

Seramat, stated that improper disposal of feces cause environmental pollution and foul odors and damage the aesthetics [9]. Mubarak and Chayatin, stated that the disposal of feces in any place can cause transmission of various diseases [10]. According to Mubarak, Lilis, and Joko, that as for the diseases transmitted through feces include: Amoebiasis, Cholera, Stigellosis, Poliomyelitis, and Typhoid disease [11]

Ibeng, explained that: In general, the definition of sanitation is an effort made by humans in realizing and also guaranteeing environmental conditions (especially the physical environment, namely land, water, and air) that meet health requirements [12]. Environmental sanitation has a big role in preventing the occurrence of this stunting. WHO in 2018 announced that Indonesia was ranked the second worst sanitation in the world after India [13]. Based on Susenas data, BPS in 2017 said that only $72 \%$ of the population had access to adequate sources of drinking water. Likewise, the percentage that has access to proper sanitation is only $68 \%$ [14]. Notoatmodjo, stated that environmental sanitation is the health status of the environment which includes housing, sewage disposal, clean water supply and so on [8]. Franceys and Reed, stated that environmental sanitation is a collection and disposal system of human waste (septictank), liquid waste, disposing of waste so that it does not endanger individuals and society [15].

Law of the Republic of Indonesia Number 32 of 2009 concerning Environmental Protection and Management, Article 1 states that the Environment is: the unity of space with all objects, power, and conditions, and living things, including humans and their behavior, which affect the continuity of life and well-being humans and other living things [1]. Adnani, divides the environment into 3 parts namely: (1) Biological Environment, which is environmental elements that are biological in nature that can be a source of food and a source of disease, (2) Physical environment, namely environmental elements in the form of soil, air, climate water which is basic human needs, (3) Social Environment, namely the environmental elements in the form of economic systems, traditional community organizations and various human services to humans [16]. According to Frytxell \& Lo, stating that environmental knowledge can be interpreted as knowledge that contains reality, concepts, and interactions with the natural environment and the whole ecosystem [17].

\section{Research Method}

The specific objectives of this study are: (1) to design a family latrine construction model that uses local raw materials for a weak economy community in the highlands of
South Sulawesi province that is environmentally safe, (2) to find local materials that make up the latrine construction, and (3) find the right method for applying the latrine construction model. The research locations were the highlands of Maros Regency, Barru Regency and Soppeng Regency. The respondents of this study were 150 families were also selected purposively. The research variables are: (1) the family toilet construction model, (2) the construction material of the latrine construction, and (3) the method for applying the latrine model. Data collection by questionnaire. The analysis used is descriptive qualitative analysis.

\section{Results and Discussion}

\subsection{Model Construction of Latrine Family of Weak Ecnomi Communities in the Plateau Region of South Sulawesi Province}

\subsubsection{Stool Collection Tub Construction}

The analysis of 150 respondents showed that $93.33 \%$ chose a brick pair. As many as $4 \%$ chose buis concrete. As many as $2.67 \%$ chose bamboo pegs. No respondent wants land excavation. Based on this description it can be understood that the construction of fecal shelters desired by the weak economy community in the highlands of South Sulawesi Province is a brick pair. The construction appears above the ground level as high as 40 to $50 \mathrm{~cm}$.

\subsubsection{Seepage Construction}

The results of an analysis of 150 respondents showed that, as much as $96.67 \%$ chose a layer of split stone, gravel, sand, and fibers for the construction of seepage in the side of the stool. As many as $2 \%$ choose a layer of gravel, palm fiber and sand for seepage construction of the side of the stool. As many as $1.33 \%$ choose gravel and sand layers at the bottom of the stool bath as seepage construction. Based on this description it can be concluded that the seepage construction consists of layers of split rock, gravel, sand, fibers, and seepage pipes from paralon pipes, well constructed which are located next to the stool-like construction.

\subsubsection{Latrine Construction (Toilets) and Used Toilets}

The results of an analysis of 150 respondents showed that, as much as $66.67 \%$ chose a simple ceramic floor, goose neck toilet. As many as $33.33 \%$ chose the goose neck toilet floor cement floor. None of the respondents chose flatbed brick floors and cemplung toilet bricks. Based on this description it can be concluded that the construction of the toilet floor is a simple ceramic floor and a cement floor with a swan neck toilet.

\subsubsection{Bathroom Floor Construction.}

The results of an analysis of 150 respondents showed that, as many as $50 \%$ chose simple ceramic floors. As many as $50 \%$ choose cement floor. No respondent chose brick floor on the floor and brick floor only. Based on this description it can be concluded that the bathroom floor construction is a simple ceramic floor and cement floor floor. 


\subsubsection{Bathroom Bathtub Construction}

The results of an analysis of 150 respondents showed that, as many as $80 \%$ chose a simple ceramic stone pair. As many as $20 \%$ choose a pair of fine brick plastered. No respondent chose a pair of coarse plastered brick and a plaster pair without plaster. Based on this description, it can be concluded that the construction of the bathroom bathtub is a simple pair of brick fitted with a simple ceramic and a pair of fine brick plastered.

\subsubsection{Latrine Wall Construction}

The results of an analysis of 150 respondents showed that, as many as $50 \%$ chose the construction of the latrine wall of a pair of smooth plastered bricks. As many as $26.67 \%$ chose bamboo walls. As many as $23.33 \%$ chose local wooden planks. No respondent chose the zinc wall. Based on this description it can be concluded that the construction of latrine walls is a pair of smooth plastered bricks, banmboo walls, and local wooden planks.

\subsubsection{Latrine Roof Truss (WC) Construction}

The results of an analysis of 150 respondents showed that, as many as $20 \%$ chose second-class wood for the toilet roof truss. As many as $80 \%$ choose local wood. No respondents chose first-class wood and bamboo. Based on this description it can be concluded that the construction of latrine roof truss is local wood and second class wood.

\subsubsection{Latrine Roof Cover (WC) Construction}

The results of an analysis of 150 respondents showed that $33.33 \%$ chose a zinc roof as a latrine roof cover. As many as $25.34 \%$ choose local wood. As many as $41.33 \%$ chose bamboo. There were no respondents who chose first-class wood and roof tiles. Based on this description it can be concluded that the construction of latrine roof coverings is zinc, local wood and bamboo.

\subsubsection{Latrine Door Construction (WC)}

The results of an analysis of 150 respondents showed that, as many as $20 \%$ chose a local wooden door frame coated with zinc plate. As many as $80 \%$ choose local wooden plank doors. No respondent chose first-class wooden panel doors and bamboo doors. Based on this description it can be concluded that the construction of latrine closing doors are local wooden plank doors and local wooden frames coated with zinc plate.

\subsection{Local Materials Used or Compiled for the Construction Model of Latrine Weak Family Economy in the Plateau Region of South Sulawesi Province}

\subsubsection{Local Material Used for Stool Body Construction}

The local material used as a compiler for fecal tub construction is described as follows. Of the 150 opinions of respondents who were analyzed, as many as 145 respondents $(96.67 \%)$ stated that the material making up the construction of a stool is: bricks, sand, and cement for masonry. A total of 5 respondents (3.33\%). states: sand, gravel, and cement for concrete buis pairs. Based on this description it is concluded that the constituent materials for construction of feces are: sand, gravel, bricks, and cement. Material for the construction of faecal tub construction, the price is affordable for the weak economy community and is widely available in the highlands in South Sulawesi Province.

\subsubsection{Local Materials Used for Seepage Construction}

The local material used as seepage construction materials are described as follows: Of the 150 respondents whose opinions were analyzed, 147 respondents (98\%) stated that the constituent material for seepage construction was: split stone, gravel, sand, seepage pipes, and fibers. A total of 3 respondents $(2 \%)$. states that: sand, gravel, and palm fiber. Based on this description it can be concluded that the constituent materials for seepage construction are: Gravel, sand, seepage pipes and fibers. The permeating construction constituent material, the price is affordable by the weak economy community and is available in many areas in the highlands in South Sulawesi Province.

\subsubsection{Local Materials Used for Construction of Latrines and Toilet Closets}

The local material used as a constructor for latrine floor construction is described as follows. Of the 150 respondents whose opinions were analyzed, 75 respondents $(50 \%)$ stated that the material for constructing latrine floor construction was: local ceramics, bricks, sand, cement, and locally made goose-neck closets. As many as 75 respondents (50\%) stated that: sand, gravel, cement, kolesed goose neck. Based on this description, it can be concluded that the building material or materials used for the construction of latrine floors are: local ceramic, bricks, gravel, sand, and locally made goose neck closets. Construction material for latrine floor construction, the price is affordable for the weak economy community and is available in many areas in the highlands in South Sulawesi Province.

\subsubsection{Local Materials Used for Bathroom Floor Construction}

The local material used as a compiler for bathroom floor construction is described as follows. Of the 150 respondents whose opinions were analyzed, as many as 90 respondents $(60 \%)$ stated that the building material for the bathroom floor construction was: local ceramics, bricks, sand, and cement. A total of 60 respondents $(40 \%)$ stated that: sand, gravel, and cement. Based on this description it can be concluded that the constituent materials or materials used in bathroom floor construction are: local ceramic, bricks, gravel, and sand. Construction material for latrine floor construction, the price is affordable for the weak economy community and is available in many areas in the highlands in South Sulawesi Province.

\subsubsection{Local Materials Used for Construction of Water Tubs in the Bathroom}

The local material used as a compiler for the construction of a water bath tub is described as follows. From 150 
opinions of respondents who were analyzed, as many as 140 respondents $(93.33 \%)$ stated that the constituent materials for the construction of water tanks in the bathroom were: local ceramics, bricks, sand, and cement. A total of 10 respondents $(6.67 \%)$ stated that: sand, gravel, and cement. Based on this description it can be concluded that the constituent materials or materials used in the construction of water tanks in the bathroom are: local ceramics, bricks, gravel, and sand. This water bath construction material, the price can be reached by economically weak communities and is available in many areas in the highlands in South Sulawesi Province.

\subsubsection{Local Materials Used for Latrine Wall Construction}

The local material used as a compiler for pit latrine construction is described as follows. Of the 150 respondents whose opinions were analyzed, as many as 75 respondents (50\%) stated that the material making up the construction were: local ceramics, bricks, sand, bricks, and cement. A total of 15 respondents (10\%) stated that: local and zinc wood blocks. A total of 60 respondents (40\%) stated local beams and wooden boards. Based on this description it can be concluded that the constituent materials or materials used for the construction of latrine walls are: sand, brick, sand, blocks and local wooden boards. Construction material for latrine wall construction, the price is affordable by the weak economy community and is widely available in the highlands in South Sulawesi Province.

\subsubsection{Local Material Used for Latrine Roof Frame Construction}

The local material used as a constructor for latrine roof truss construction is described as follows. Of the 150 respondents whose opinions were analyzed, 148 respondents $(98.67 \%)$ stated that the material for the construction of the roof truss construction was local wood. A total of 2 respondents $(1.33 \%)$ stated that second-class wood. Based on this description it can be concluded that the building material or material used for the construction of latrine roof truss is local wood. Material for constructing latrine roof truss construction, the price is affordable for the weak economy community and is widely available in the highlands in South Sulawesi Province, even the material is not purchased.

\subsubsection{Local Materials Used For Latrine Roof Cover Construction}

The local material used as a compiler for pit latrine construction is described as follows. Of the 150 respondents whose opinions were analyzed, as many as 50 respondents $(30 \%)$ stated that the material making up the roof construction was zinc. A total of 60 respondents (40\%) stated that local wood. And as many as 50 respondents (30\%) stated bamboo. Based on this description it can be concluded that the constituent materials or materials used in the construction of latrine roof coverings are zinc, local wood, and bamboo. Construction material for latrine roof cover construction, the price is affordable for the weak economy community and is widely available in the highlands in South Sulawesi Province.

\subsubsection{Latrine Door Construction (WC)}

The analysis of 150 respondents showed that, as many as $20 \%$ chose a local wooden door frame coated with zinc plate. As many as $80 \%$ choose local wooden plank doors. No respondent chose first-class wooden panel doors and bamboo doors. Based on this description it can be understood that the construction of latrine closing doors is local wooden plank doors and local wooden frames coated with zinc plate. Local wooden board door construction and local wooden frame door coated with zinc plate, can be done easily by the local community. Local wood is widely available and the price can be reached by economically weak communities in the highlands of South Sulawesi Province, even the local wood is not bought by the local community. Door constructs like this if done well will last a long time and are easy to maintain.

\subsection{Steps or Methods for Applying the Latrine Model of the Weak Community Economy in the Highlands of the South Sulawesi Province}

\subsubsection{Introducing the Latrine Model}

The results of the analysis of 150 respondents showed that as many as $80 \%$ stated strongly agree. A total of $18.67 \%$ agreed. As many as $1.33 \%$ who said they did not agree. And there were no respondents who stated strongly disagree. Based on this description, it can be concluded that to apply the family toilet model for the weak economy community in the highlands of South Sulawesi Province is to introduce the construction structure and material used or the latrine model as a first step.

\subsubsection{Provide an Explanation of the Purpose and Benefits of Latrines}

The analysis of 150 respondents showed that $66.66 \%$ of them stated strongly agree. As many as $33.34 \%$ agreed. And there were no respondents who stated disagree and strongly disagree. Based on this description, it can be concluded, that to apply the family toilet model for the weak economy community in the highlands of South Sulawesi Province is to provide an explanation of the purpose and benefits of the latrine to humans and the environment as a second rarity.

\subsubsection{Provide an Explanation of the Impact of Feces Thrown Away}

The results of the analysis of 150 respondents showed that as many as $50 \%$ stated strongly agree. As many as $50 \%$ who agree. There were no respondents who said they did not agree and strongly disagreed. Based on this description, it can be concluded, that to implement the family latrine model for the weak economy community in the highlands of South Sulawesi Province is to provide an explanation of the impact of feces dumped anywhere as a third step.

\subsubsection{Introducing and Explaining the Local Materials Used}

The results of the analysis of 150 respondents showed that as many as $60 \%$ stated strongly agree. As many as $40 \%$ 
agreed. And there were no respondents who stated disagree and strongly disagree. Based on this description, it can be concluded, that to implement the family latrine model for weak economic communities in the highlands of South Sulawesi Province is to introduce and explain the local material used as a fourth step.

\subsubsection{Providing Pilot Model Latrine for Weak Economic Families in the Highlands Region}

The analysis of 150 respondents showed that $86.67 \%$ of them stated strongly agree. A total of $13.33 \%$ agreed. And there were no respondents who stated disagree and strongly disagree. Based on this description, it can be concluded, that to implement the family latrine model for weak economy communities in the highlands of South Sulawesi Province is to provide a model of latrine models for weak economy families in the highlands region.

\section{Conclusion}

The conclusions of this study are as follows: 1) The family latrine construction model for a weak economy community in the highlands region of South Sulawesi Province consists of: a red stone pair stool collection facility equipped with a seepage system, walls and floor of a red stone pair, and a swan neck toilet, 2) The local materials making up the construction, namely red stone, sand, gravel, and fibers, 3) The method adopted for implementing the family toilet model is: introducing the model and material used, explaining the purpose and benefits of the latrine, and providing a pilot.

\section{Acknowledgements}

Thank you to: 1) Rector of Makassar State University (UNM) as the supervisor of the UNM Lecturer in conducting research and community service, 2) Directorate of Research and Community Service Directorate General of Strengthening Research and Development Ministry of Research, Technology and Higher Education has provided research funds in the context of fostering lecturer research at universities especially at UNM, 3) Chairperson of the Institute for Research and Community Service (LP2M) UNM for his direction as the person in charge of research and community service activities, 4) Secretary of the Research and Community Service Institute 5) Regents of Soppeng, Bone and Maros who have given permission to conduct research in the area or regency, 6) Head of Departement of Settlement and infrastrukture Facilities in Soppeng, Bone, and Maros Regency for their willingness to become facilitators in research activities, and 7) All lecturers and students, as well as all parties who have taken part in carrying out this research.

\section{References}

[1] Undang-undang Republik Indonesia Nomor 32 tahun 2009 tentang Perlindungan dan Pengelolaan Lingkungan hidup.

[2] Dyah Widiastuti, Anggun Paramita Djati, Nova Pramestuti. 2017. Biotic and Abiotic Factors in Anopheles spp. Breeding Site at Gunung Jati Village, Pagedogan Sub-District, Banjarnegara, Central Java Province. BALABA Vol. 13 No. 2, Desember 2017: 153-162.

[3] Tandjung, S. D. 1991. Ekofilosofi, IPTEK dan Lingkungan Hidup. Makalah Seminar Penduduk dan Lingkungan Hidup. Yogyakarta: PAU UGM.

[4] Depkes RI. 2002. Profil kesehatan Indonesia 2001 Menuju Indonesia sehat 2010. Jakarta: Departemen Kesehatan RI. 2002: 40 .

[5] Chandra, Budiman. 2007. Pengantar Kesehata Lingkungan. Jakarta: Buku Kedokteran EGC.

[6] Salvato, Joseph dan Joe E, Beck. 1994. Environmental Engineering and Sanitation. Newyork: United States of America.

[7] Firmansyah. 2009. Memiliki dan menggunakan Jamban Sehat. http://www. wordPress.com. Diakses 25 Mei 2015.

[8] Notoatmodjo, S. 2007. Promosi Kesehatan dan Ilmu Perilaku. Jakarta: Rineka Cipta.

[9] Seramat, B. 2003 Gambaran Karakteristik Kepala Keluarga Dengan Kepemilikan Jamban Keluarga Di Wilayah Kecamatan Kaliwungu Kabupaten Kendal (Survei Cepat Pada Bulan JuniAgustus 2003). Undergraduate Thesis, Diponegoro University.

[10] Mubarak, Wahit \& Chayatin. 2008. Buku Ajar Kebutuhan Dasar manusia Teori dan Aplikasi dalam Praktik. Jakarta: EGC.

[11] Mubarak W. I., Lilis I., Joko S. 2015. Buku Ajar Ilmu Keperawatan Dasar. Jakarta: Salemba Medika.

[12] Ibeng, Parta. 2017. Pengertian Sanitasi. Pendidikan. Co.Id https://pendidikan.co.id/teks-eksplanasi/

[13] Antonio, W. H. O, \& Weise, S. 2018. WHO Global Nutrition Targets 2025: Stunting Policy Brief.

[14] BPS. 2018. Eksplorasi Data Susenas untuk Intervensi Stunting. Pra WNPG XI.

[15] Franceys, R., Pickford, J. \& Reed, R. 1992. A Guide to the Development of On-Site Sanitation, Geneva: World Health Organization

[16] Adnani, H., 2011. Ilmu Kesehatan Masyarakat, Cetakan 1, Penerbit Nuha Medika, Yoyakarta.

[17] Frytxell, Gerald E. \& Lo, Carlos W. H. 2003. "The Influence of Environmental Knowledge and Values on Managerial Behaviours on Behalf of the Environment: An Empirical Examination of Managers in China."Journal of Business Ethics 46 (1): 45-69 (2003). 